\title{
Ergonomic Design of Table and Chair based on QFD and Anthropometric Measurement and improved Facility Layout
}

\author{
Taposh Kumar $\mathbf{K}^{1 *}$, Mustafizur $\mathbf{R}^{1}$, Muhammad AdibUz $\mathbf{Z}^{2}$ and Moin \\ Uddin $\mathrm{G}^{1}$ \\ ${ }^{1}$ Depatment of Industrial and Production Engineering, Jessore University of Science and \\ Technology, Bangladesh \\ ${ }^{2}$ Depatment of Industrial and Systems Engineering, Northern Illinois University, USA
}

\section{Research Article}

Volume 2 Issue 3

Received Date: April 23, 2018

Published Date: May 14, 2018

DOI: $10.23880 /$ eoij-16000146

*Corresponding author: Taposh Kumar Kapuria, Dept. of Industrial and Production Engineering, Jessore University of Science and Technology, Jessore-7408, Bangladesh, Email: sabita.kapuria@gmail.com

\section{Abstract}

This study analyzed the probable mismatch between university table and chair dimensions and anthropometric characteristics of 200 Bangladeshi (Jessore University of science \& technology) students and emphasize on student needs. Comfortable learning in a classroom depends on a number of concealed factors and appropriate university furniture like tables and chairs. Ergonomically fit tables and chairs ensure the comfortable learning facilitation. However, an anthropometric survey showed that most of these tables and chairs were not made according to ergonomic considerations. Fifteen anthropometric measurements are considered and nine dimensions from the existing classroom tables and chairs were measured and compared to identify the probable mismatch between them. Here, QFD tool is used. For obtaining the important ratings of the student's demands for QFD, a survey was held. By using QFD tool, final design requirements are prioritized. The paper recommends the dimensions for ergonomically fit tables and chairs and also represents the facility layout of one of the specific university classrooms of the Bangladesh to allocate the available tables and chairs. Finally, new ergonomically fit new designs are proposed. As students spend most of their time in the classroom, it is very essential to supply appropriate tables and chairs for them. Long time sitting on those inappropriate tables and chairs can cause musculoskeletal disorders.

Keywords: Ergonomic design; QFD; Anthropometric measurement; Design; Layout

\section{Introduction}

Classroom furniture namely table and chair are considered important physical elements of the learning environment. Human health is notably impacted by the furniture and the arrangement of the body and its limbs. An anthropometric survey showed that incorrect furniture dimensions are responsible for discomfort, pain and disorders, namely in back, neck, shoulder, and hands, wrists and 


\section{Ergonomics International Journal}

many musculoskeletal diseases. Thus, it is very important to design the classroom furniture more specifically table and chair considering the anthropometric dimensions and ergonomic guidelines.

On an average, studying time in a typical university of Bangladesh is from 9AM to 5PM. So, it is clear that students generally spend their maximum time in the classroom. Almost 75\% of that time is put to use by sitting on the table and chair to do the university work. Experts think that the designing of classroom furniture seems to be more important than designing workplace furniture. So, the situation seems very serious. In this case, higher authority of the university needs to pay attention to build a classroom table and chair by following the anthropometric measurement and ergonomic guidelines. In Bangladesh, table and chair in the classrooms are of low quality and made with non-smooth wood surface. As a result, it causes very rough writing surface and ergonomic problems.

In this study Quality function deployment (QFD) is also used. A student survey was held to identify the student comfort requirement. With QFD, design requirements are assigned to the student's demand, according to the direction of experts in these fields. Finally, design requirements are prioritized. Prioritized design requirements tell which design requirements are necessary at first to start the work. Total 200 students are surveyed to get the anthropometric data. Then the mismatch between needing anthropometric measurement and an existing tables and chairs is identified which leads to design the ergonomic table and chair for the students.

In this study, facility layout is also included. Layout of 233 (A) classroom of 4th year, Industrial and Production Engineering, Jessore University of science and technology is also used. This layout shows how many tables and chair can be allocated in that room. Also, some extra facilities for the students is recommended. By using those extra facilities, learning activities should be more comfortable.

After reviewing the literature on QFD, ergonomics \& facility layout, a methodology is proposed which includes the QFD for identifying and satisfying student's needs, anthropometric measurement for anthropometric dimensions of the students, classroom furniture measures, mismatch between university furniture and body dimensions. Finally, results are proposed and implemented.

\section{Literature Review}

\section{Review of Literature on QFD}

Hamada [1] used QFD tools for quality enhancement in curriculum plan and teaching strategies to meet with customer requisites. He applied QFD methodology to a university cause in accounting. It helps him determine the genuine customer requisites. Here, QFD allows him to classify the wisdom needs of students in an accounting course and then, students need convert into educational strategies which pacify student's requirements. The finishing outcomes allowed to him to determine the lawful things to do for the first time. The footstep is to do QFD strictly is to decide purchaser prospect appropriately. It is key to pacify customer necessities.

Fransis [2] showed an engineering approach with quality function deployment for an accreditation board of engineering and technology. He said sensation of a quality function deployment (QFD) inquiry is basically on the quality of the speech of the customer, more specifically the customer requirements and their importance ratings. He applied QFD, on a main cause of mechanical engineering plan, where the considered cause wisdom results as a speech of the customers (what) and students issued by ABET as a technical requirements (How).The prime objective of that paper was to tarmac a clear road to faculty members and engineering institutions to gratify the ABET requisites.

Sandra, et al. [3] added quality function deployment and logical frame work to improve of emergency care in Malta. Here, he used QFD to identify and analyze issues and challenges of the accident and emergency (A\&E) department. In this case logic framework approach helps to develop detailed project plans for quality improvement. The main purpose of combined QFD is to improve the process and system performance substantially.

Danuta Kunecka [4] stated that quality function deployment method enables rational design of service. It's not only technical prospective view but also cause of market and customer needs. House of Quality returns as a medium of transmit to customer expectations. He applied quality function deployment replica made by "Bartoszsolin S14" in his paper "Development of the quality of educational the nursing practice". 


\section{Ergonomics International Journal}

In this paper, he applied QFD on different stages of quality management process to uplift of practical training of nurses. Katerina, et al. [5] applied quality function deployment model in a housing association located in the United Kingdom. By applying QFD here, they improved a company's exhibition. They successfully adopted, applied and utilized the QFD tool within the challenging of social housing and other sectors. The trial result had an absolute effect upon a company for developing statement-based policy of operational exchanges, pilot and progress.

Hatice Cemgoz Akdog, et al. [6] employed quality function deployment plan for translating internal client needs and expectations into suitable benefit enumeration for increasing internal client pleasure. He integrated SERVQUAL into QFD to set the prosperity Factors to improve quality in the textile industry. Cordeiro and Barbosa [7] applied customized QFD to management of automation projects. The cardinal contribution at this paper was a new matrix to assist the project manager to design requirement verification over project by using team skills based on client needs. They used proposed customized QFD to identify a set of requirements for each project phone which are difficult to project success.

Li and song [8] used Rough VIKOR-based audit function deployment model for prioritizing design attributes of product connected service. Emarh, et al. [9] investigated multi-agent service quality difficulty in the area of air management. They used QFD model to compromise the needs of airlines and passenger to assure the quality implementation. Here, multidimensional QFD model is used which is able to analyze the needs of all agents instead of traditional QFD model to obtain suitable solutions.

Nora and Noor [10] used quality function deployment model to decide the employers collection criteria for selecting students for the industrial training arrangement by using quality function deployment model by obtaining feedback from the employers out there. They found from the study that communication skills and students' participation in sports and co-curricular activities in the university are the most important design selection criteria. They utilized QFD approach to convert employers' feedback improving marketability of the students.

Lonica and Leba [11] integrated quality function deployment in the new product deployment cycle.
They proposed a methodology to estimate the voice of customers to design innovative products. They applied this method on a biometric selection system for emergency cases. They followed QFD steps to develop a mathematical model which was quantified by an overall index. Takeo, et al. [12] stated that because of rapid growing and communication technology, high functionality is not the only one, pliability is also to cooperate with the others. They used M-QFD model which means multi-space quality function deployment. By suing M-QFD model which helps designer to develop the elements based on various needs such as client needs, company and society needs etc.

Moradi and Raissi [13] improved client gratification by using QFD in benefit quality analysis; especially they applied the QFD methodology and mathematical optimization to update the Tehran's metropolis service. As a result, proposed system reduced the gap between metropolis managers and citizens. The trial results also showed that QFD was an operating tool for them to permit metropolis managers to trial out the demand of the citizens and to reserve with engineering and technical requirements. Jian, et al. [14] investigated how to prioritize engineering characteristics based on client online survey to valuable client requirement. They used an integer linear programming model to change the couple sapient results into initial client pleasure ratings. They also got client sentiment regarding engineering characteristics. Finally they revealed the merits of the proposed approach.

Romeo, et al. [15] used awareness and capability of Quality Function Deployment in plan and construction projects in Nigeria. Basically, they had applied the QFD tools in the construction industry in developed countries. In reality, developing countries such as Nigeria have not been practically aware about the profit of QFD, simply they investigated the awareness and effectiveness at quality function deployment. They improve the satisfaction of client in terms of quality, cost and project delivery time in design and construct plan.

Cerit B, et al. [16] applied quality function deployment model on a Smartphone pattern. They explored the application of quality function deployment on a new product, Smartphone improvement is consistent with client satisfaction. It was for Turkeys leading mobile communication operator to design a Smartphone. Here, QFD was used 


\section{Ergonomics International Journal}

to obey the voice of customer and quality management technique was used to give guarantee the quality to the product or service. They also used Kano model during the grouping and prioritization of the client necessities.

\section{Review of Literature on Ergonomics}

Samuel, Joel, Freivalds [17] showed that children have been known to spend over $30 \%$ of their time at school. Most classroom activities include sitting for long periods of time, with little or no breaks. Every exertion should be made to confirm that teenage children do not have back pain and other musculoskeletal disorders due to elongated sitting on the improperly designed classroom furniture. The anthropometric measures of twenty first graders were used to improve regression equations for the furniture dimensions. The inquiry of pertinent anthropometric measures such as stature, weight, Body Mass Index (BMI), popliteal height, buttock popliteal length and hip breath shows that stature and body mass index are vital factors in sketching out the classroom furniture.

Rungtai Lin and Yen-Yu Kang [18] showed that the conventional chair and desk are not capable of fitting all students with various body figures. How to gain the requirements of students for various body places is the main deliberation in this study. The procedures adopted for the assessment involve the present school furniture survey, a plan analysis and personal comfort estimation. Then, the result of study focuses on the application of an anthropometric survey of school in Taiwan. Finally, based on the anthropometric database, the anthropometric deliberations of school furniture are suggested for designing the primary school furniture desks and chairs in Taiwan. The design approximately proposed a series of desks and chairs adjustable to ergonomic issues.

\section{Review of Literature on Facility Layout}

Pedro and Rui [19], the design of facility layouts involves in a decision process which, in common, its complexity, has to be decomposed into several subproblems, namely: the selection of the most sufficient manufacturing processes, the planning of the equipment and worker needs, the allocation manufacturing operators to machines, the grouping of machines into sections, the selection of selection handling, the specification of work-in-process parking areas and the definition of the location machines and sections on the manufacturing plant.

Heragu and Kusiak [20] two new models of the facility layout problem are presented: linear continuous with absolute values in the objective and constraints and linear integer. The linear mixed integer models have lesser number of model integer variables than any other existing formulating of the facility layout problem. While most other linear mixed-integer models available in the literature obtained through a linearization of the quadratic assignment problem. An advantage of the formulations presented in this paper is that the location of sites need not be known a priori. More importantly, two of the formulations model the layout problem with facilities unequal area. Solving the models presented with an unconstraint optimization algorithm yields good quality suboptimal solutions in a relatively low computation time.

Angel ford [21] the places where high school teachers teach have a relationship with what and how their students learn. Certain aspect of the physical environment have been examined decades, such as those affect basic physiological needs including but not limited to climate control, air quality, appropriate lighting and cleanliness. It is significant to investigate knowledge spaces in light of changing pedagogies that teachers are being encouraged to take on this young generation of students. Without the suitable facilities, teachers are restricted in the pedagogical techniques they can apply. As teachers are being needed to separate teaching strategies, they want to be supplied with the suitable resources, including the most effective physical environment and classroom layout and the training to take those spaces effectively.

Cheryan and Ziegler, et al. [22] indicated that developing student attainment is essential to their nation competitiveness. Scientific research shows how the physical classroom environment influences student attainment. Two findings are key: first the morphological facilities keenly mastery wisdom. Insufficient lighting, sound, low air quality and deficient warming in the classroom importantly connected to worse students' attainment. Over half of U.S. schools have insufficient morphological facilities and student are likely to attend schools with deficient morphological facilities. Second, scientific studies uncover the unforeseen significance of a classroom's emblematic aspect, such as objects and well décor, in 


\section{Ergonomics International Journal}

influencing student learning and acquirement in this environment. Emblematic report students whether they are valued learners and go to the classroom, with far reaching consequences for students' academic likes and attainment. They contour rule connections of the scientific discovers-noting pertinent rule audiences and specify crucial aspects of classroom design that can develop student attainment, particularly to the most unprotected students.

\section{Methodology}

Participants are selected randomly for conducting the data collection. Questionaries' are prepared to identify the student's requirements. QFD is used to prioritize the design requirements. Different types of anthropometric measurements are discussed for understanding the data collection. University classroom furniture measures are also discussed. Mismatch calculation procedure between the furniture and body dimensions is also shown. Finally, facility layout is described.

\section{Participants}

For the purpose of this study 200 students were taken from many university of Bangladesh, in order to collect various anthropometry measurements. Dimensions of existing furniture are also taken in order to find out mismatch with anthropometric measurements.

\section{Procedure}

Student survey by considering Kano model was held at the beginning. Student's requirements are identified to meet the satisfaction. Then another survey was done by considering quality function deployment model. After getting student demands, House of quality is prepared to prioritize design requirements. Then anthropometric measurements of the students were taken. Also, dimensions of existing furniture are also taken to calculate mismatch. From the anthropometric measurements- mean, max, min, standard deviation, $5^{\text {th }}, 50^{\text {th }}, 95^{\text {th }}$ percentiles are calculated. Then design of layout is prepared to allocate the table and chair.

\section{Quality Function Deployment}

Quality function deployment is a total quality management tool which represents all the analysis structurally. QFD translates customer demand into design requirements for better customer satisfaction. This total quality management tool was first introduced in Japan back in 1972.

This tool is widely used in various sectors such as product development, manufacturing industries, educational institution and service providers to improve their customer service level. In general, quality function deployment method finds out the customer demand through voice of customer (VOC). Then designed requirements are assigned to that customer demand.

Finally, customers get responsive and improved product to get better value from it. QFD method is basically based on customer survey. Then rest of the steps come to the front. Certain level of Questionnaire development is the first initial stage of starting QFD process.

Appropriate questionnaire development to get the best "Voice of the customer" which reflects the better satisfaction. There are many ways of taking customer survey such as with hard copy of questionnaire, telephone call etc. Then VOC translated into interpreted need. Quality function deployment structured process is listed below.

\section{Step 1: Questionnaire Development}

Appropriate questionnaire development is the best way to capture customer demand. In this step to build questionnaire, we arranged a meeting of experts who basically works with ergonomic research, human factor engineers, students of ergonomics and other experts in this field. For chair and multifunctional table, we had developed 12 questions for chair and 15 questions for multifunctional table. Among them, we have kept 9 questions for chair and 11 questions for multifunctional table. Added that, unnecessary questions are reduced because of expert opinions.

\section{Step 2: Identifying customer requirements}

From the survey, we got "Voice of customers". Then Voice of customer is translated into interpreted need. Based on these customer demands, later designed requirements are assigned.

\section{Step 3: Determining the relative importance of WHAT's}

To get the relative importance of WHAT's, SATTY's pair wise comparison table was used to capture the importance. Also mentioning that, getting importance 
score is varied from one customer to another customer. And the importance level was 1-9.

\section{Step 4: Establishing Design requirements}

After getting customer demands, the next vital step is establishing design requirements. In this step, top level experts are involved to build best design requirements for the articulated customer demand. The main target to call experts in these fields was to fulfill the customer demand and to obtain better customer satisfaction.

\section{Step 5: Preparing inter-relationship matrix between WHAT and HOW}

Inter-relationship matrix is an essential part of House of Quality. This inter-relationship matrix represents "HOW" well design requirements are related with customer demand "WHAT". The higher accuracy of the inter-relationship matrix means better customer satisfaction.

\section{Step 6: Determining of the technical ratings of "HOW"}

Technical ratings of "HOW" are calculated through multiplication of two factors, Final importance ratings of WHAT and the relationship between design requirements and customer requirements.

Technical rating of Design requirements $=$ Final importance ratings of WHAT $\times$ Interrelationship matrix

\section{Step 7: Prioritizing of Design requirements}

The final step of quality development process is prioritize the design requirements. Basically from these steps a company determines the essential design requirements needed to be utilized for the specific product. Here, design requirements are prioritized through their relative weight percentage. Higher to lower score form is used to prioritize design requirements here.

\section{Anthropometric Measurements}

Anthropometric Dimensions of the Students: Anthropometric measurements used as a key word during designing furniture ergonomically. The Sitting elbow height: Calculated to the vertical distance from a horizontal sitting surface to the tip of the elbow with fixed at 90 degrees. It assists to determine table height. anthropometric measures were gathered to the seated and standing positions in a bar foot. During measurements, care was taken to be sure the individual was sitting upright and that students feet were perpendicular to the ground using a chair. The following anthropometric measurements were taken for each student:

Sitting height: Calculated to the vertical distance from a horizontal sitting surface to the height point of head. This is utilized to find out the vertical clearance required for a seated posture.

Sitting eye height: Calculated to the vertical distance from a horizontal sitting surface to the eye. Visual displays should be positioned under the horizontal plane defined by the eye height.

Sitting shoulder height: Calculated to the vertical distance from horizontal sitting surface to acromion (Figure 1).

Source of Image: S. O. Ismaila et al. [23].

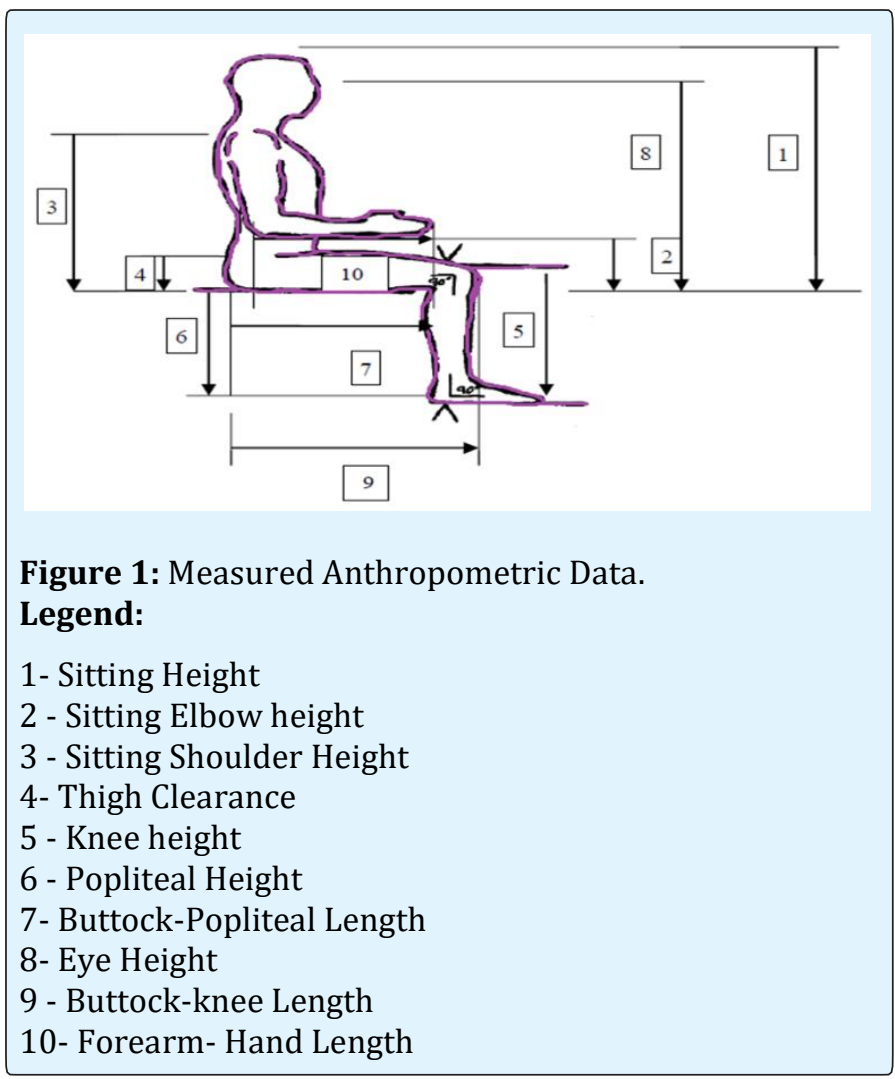

Hip breadth: Calculated to the maximum horizontal distance between the hips in the sitting position. This is used to find out the breadth of chairs and whole body 


\section{Ergonomics International Journal}

access for clearance. Hip breadth should be shorter than the furniture.

Elbow to elbow height: Calculated to the horizontal distance across the lateral surfaces of the elbows spreading sideways was calculated. This is utilized to find out the width of seat backs and distance between the arms rests.

Thigh clearance: Calculated to the vertical distance from a horizontal sitting plane to the maximum point on the thigh. Sitting elbow height and thigh clearance assist to determine how thick the table and top drawer can be.

Knee height: Calculated to the vertical distance from floor to upper surface of thigh (90 degrees of knee flexion).

Buttock knee length: Calculated to the horizontal distance from the front of the kneecap to the rearmost piece to the buttock.

Buttock popliteal length: Calculated to the horizontal distance from the posterior surface of the buttock to the popliteal surface. This is assisted to find out the length of eat pad. This length was calculated to a knee angle of 90 degree.

Popliteal height: Calculated to the vertical distance from the foot rest surface to the popliteal place. This is assisted to find out the range of adjustability for chairs. Popliteal height should be shorter than seat height.

Stature: Calculated to the vertical distance to the highest part of head, while the contributor stood erect, looking fast. This is utilized to find out the lowest skyward clearance required to evade head collisions.

University Classroom Furniture Measures: The following dimensions of the classroom furniture which are measured:

Chair Seat Height (SH): Calculated to the vertical distance from the floor to the highest point on the front of the seat.

Chair Seat Depth (SD): Calculated to the horizontal distance from the back of the sitting surface of the seat to its front.

Chair seat Width (SW): Calculated to the horizontal distance from the outer left side of the sitting surface of the seat to outer right side.

Chair Backrest Height (BH): Calculated to the vertical distance from the side of the seat surface to the highest point of the backrest.
Table Height (TH): Calculated to the vertical distance from the floor to the top of the front edge of the table (Figure 2).

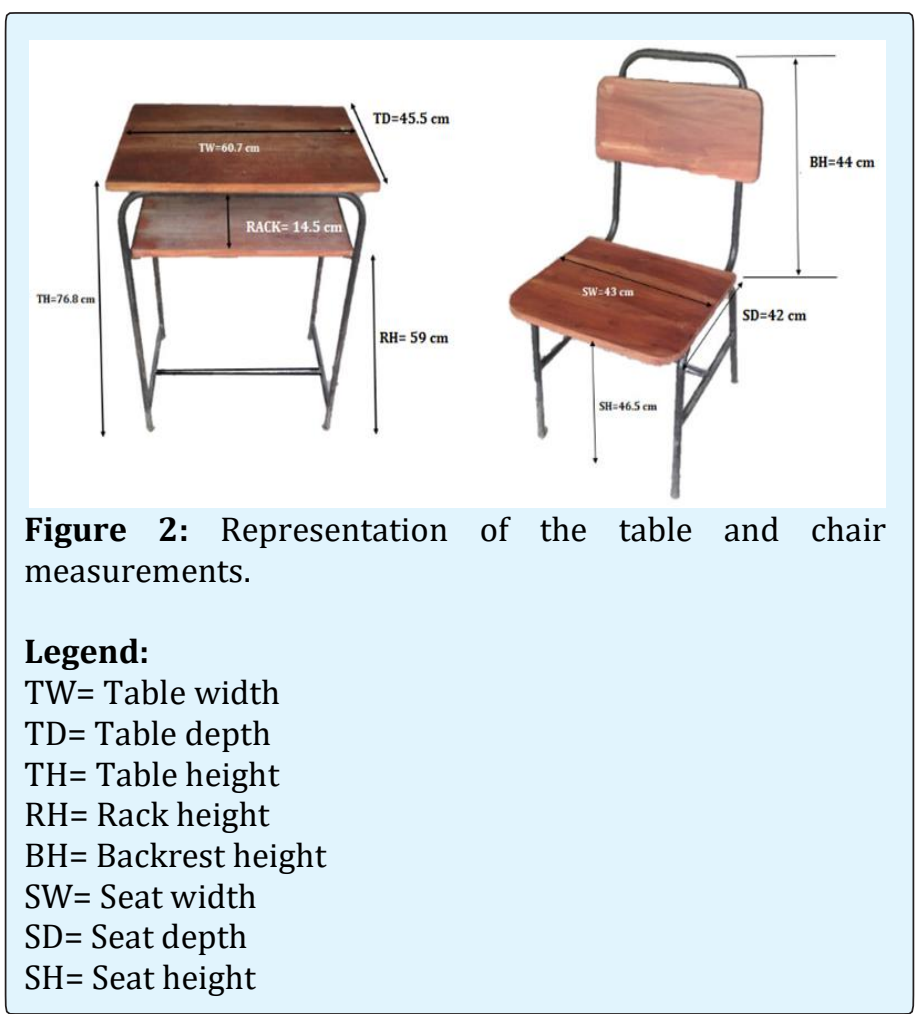

Mismatch between University Furniture and Body Dimensions: The rules of ergonomic and anthropometric should be used for designing of classroom furniture and defining the range in which suitable furniture dimension is regarded. The anthropometric measurements of every student were associated with pertinent furniture dimension in order to identify match or mismatch. In the literature various published relationships have been established to identify match or mismatch. Following equations are usually used:

Popliteal Height (PH) against Seat Height (SH): The seat height is required to be balanced with respect to the popliteal height $(\mathrm{PH})$. It additionally requires enabling the knee to be flexed with the goal that the lower legs frame a most extreme of $30^{\circ}$ point in respect to the vertical hub [24].

As per the writing, $\mathrm{SH}$ ought to be lower than the $\mathrm{PH}$ with the goal that the lower leg constitutes a $5^{\circ}-30^{\circ}$ point in respect to the vertical and the shin-thigh edge is in the vicinity of $95^{\circ}$ and $120^{\circ}$ [25-27]. Too low SH builds weight on the is chialtuberosities, though too high prompts expanded weight at the popliteal crease (underside of knees), diminishing blood dissemination and expanding 


\section{Ergonomics International Journal}

weight on the nerve. Be that as it may, $\mathrm{SH}$ does not have an esteem higher than $4 \mathrm{~cm}$ or $88 \%$ of the $\mathrm{PH}$ to maintain a strategic distance from pressure in the butt cheek area $[26,28,29]$.

Hence, $3 \mathrm{~cm}$ adjustment for shoe tallness is incorporated to the $\mathrm{PH}$ for this exploration work. A confound amongst $\mathrm{PH}$ and $\mathrm{SH}$ is characterized when the $\mathrm{SH}$ is either $>95 \%$ or $<88 \%$ of the $\mathrm{PH}$ (Parcells 1999) and it is conceivable to build up a basis for $\mathrm{SH}$ [27].

$(\mathrm{PH}+3) \quad \cos 30^{\circ} \leq \mathrm{SH} \leq$

$\cos 5^{0}$.

$(\mathrm{PH}+3)$

Buttock popliteal length (BPL) against seat depth (SD): As per Poulakakis and Marmaras [30], situate profundity ought to be no less than $5 \mathrm{~cm}$ not as much as the butt cheek popliteal length. Be that as it may, the thigh would not be bolstered enough if the SD is significantly not exactly the BPL of the subjects. Different specialists, for example, Milanese and Grimmer, Helande, Oborne, Khalil et al., Pheasant, and Sanders and McCormick [3136] clarified that the seat profundity ought to be intended for the fifth percentile of the BPL dissemination so the backrest of the seat can bolster the lumbar spine without pressure of the popliteal surface. Along these lines, confound amongst SD and BPL is characterized when SD is either $<80 \%$ or $>95 \%$ of BPL [26].

$0.80 \mathrm{BPL} \leq \mathrm{SD} \leq 0.90 \mathrm{BPL}$

Sitting shoulder height (SSH) against backrest height (BH): The proper backrest height (BH) should be considered to encourage portability of the storage compartment and arms. The estimation of the BH ought to be not as much as the scapula [29]. Subsequently, Gouvaili and Boundolos and Agha [27,37] prescribed keeping the backrest lower than or nearly on the upper edge of the scapula and an ideal $\mathrm{BH}$ ought to be kept at $60-80 \%$ of shoulder tallness. $0.60 \mathrm{SSH} \leq \mathrm{BH} \leq 0.80 \mathrm{SSH}$

Hip Breadth (HB) against Seat Width (SW): The seat width (SW) ought to be sufficiently vast to suit the client with the biggest hip broadness (HB) to accomplish dependability and permit space for sidelong developments $[27,32,33,36]$.
Also, Gutiérrez and Morgado, Evans et al., Helander, Mondelo et al., Occhipinti et al., Orborne, and Sanders and McCormick [28,29,32,33,36,38,] demonstrated that the HB ought to be smaller than the SW keeping in mind the end goal to have a legitimate fit in the seat and an ideal SW is assigned for the 95th percentile of HB conveyance or the biggest HB. The altered proposed condition demonstrates that the SW ought to be no less than $10 \%$ (to suit $\mathrm{HB}$ ) and no more $30 \%$ (for space economy) bigger than the HB [27]. $1.10 \mathrm{HB} \leq \mathrm{SW} \leq 1.30 \mathrm{HB}$

\section{Sitting elbow height (SEH) against table height (TH): $\mathrm{EH}+\quad(\mathrm{PH}+3) \quad \cos 30^{\circ} \leq \mathrm{TH}<=$ \\ $\cos 5^{0}+0.8517 \mathrm{EH}+0.1483 \mathrm{SH}$

\section{Thigh clearance against SDC:}

The appropriate SDC needs to be higher than thigh clearance (TC) in order to provide leg movement $[24,39]$. The optimum SDC should be $2 \mathrm{~cm}$ higher than knee height [26].

$(\mathrm{TC}+2)<\mathrm{SDC}$

\section{Facility Layout}

The following steps will be followed in facility layout:

a. Brainstorming about the selected room to do layout.

b. Gathering the dimension of the selected room.

Designing the layout.

Recommending extra facilities.

\section{Results}

Table 1 shows the prioritization of relative weight percentage of chair's how and table's how Table 2 shows the anthropometric measures of the student's. Table 3 shows the existing classroom furniture. Table 4 shows the number \& percentage of students who match or mismatch with existing classroom furniture Figure 3 shows the House of Quality (HOQ) for Chair. Table 5 shows the proposed classroom furniture dimensions. Figure 4 shows the HOQ for multifunctional table. 


\section{Ergonomics International Journal}

\begin{tabular}{|c|c|c|c|c|}
\hline No. & $\begin{array}{c}\text { Design } \\
\text { Requirements for } \\
\text { chair }\end{array}$ & $\begin{array}{l}\text { Weight percentage (\%) for } \\
\text { chair }\end{array}$ & $\begin{array}{l}\text { Design requirements for } \\
\text { table }\end{array}$ & $\begin{array}{l}\text { Weight percentage (\%) } \\
\text { for chair }\end{array}$ \\
\hline 1 & Foam seat & 19 & Plywood body & 18 \\
\hline 2 & Steel body & 14 & Wooden body & 13 \\
\hline 3 & Wooden body & 13 & $\begin{array}{l}\text { Position indication to keep } \\
\text { monitor }\end{array}$ & 10.5 \\
\hline 4 & Workers efficiency & 12 & Adding foot rest & 7.5 \\
\hline 5 & Cotton seat & 9 & Reducing production cost & 7.5 \\
\hline 6 & $\begin{array}{l}\text { Adding lumbar } \\
\text { support }\end{array}$ & 7.5 & Workers efficiency & 7.5 \\
\hline 7 & Adding hand rest & 7.5 & $\begin{array}{c}\text { Position indication to keep } \\
\text { keyboards }\end{array}$ & 7 \\
\hline 8 & Avoiding waste & 6 & Good finishing & 7 \\
\hline 9 & $\begin{array}{l}\text { Reducing production } \\
\text { cost }\end{array}$ & 6 & Lock system & 6 \\
\hline 10 & Colors & 2 & Adding drawer & 5.5 \\
\hline 11 & Good finishing & 2 & Medium size & 5.5 \\
\hline 12 & Best accessories & 2 & Wheel system & 4 \\
\hline 13 & & & Place for bags & 1 \\
\hline
\end{tabular}

Table 1: Prioritization of relative weight percentage of chair's how and table's how.

\begin{tabular}{|c|c|c|c|c|c|c|c|}
\hline Anthropometric dimension & Min & Max & Mean & SD & $\mathbf{5}^{\text {th }}$ \% tile & $\mathbf{5 o}^{\text {th }}$ \% tile & $\mathbf{9 5}^{\text {th }}$ \% tile \\
\hline Popliteal height & 38.9 & 48.9 & 43.21 & 2.93 & 39.04 & 42.8 & 47.75 \\
\hline Sitting height & 74.2 & 96.7 & 84.66 & 7.53 & 74.97 & 85.66 & 94.98 \\
\hline Sitting eye height & 101.2 & 131.5 & 114.87 & 11.52 & 101.38 & 113.19 & 131.49 \\
\hline Thigh clearance & 10.7 & 19.3 & 15.29 & 3.18 & 10.84 & 15.75 & 19.26 \\
\hline Sitting elbow height & 18.6 & 29.5 & 24.54 & 4.18 & 19.05 & 24.34 & 59.85 \\
\hline Buttock knee length & 4.8 & 63.7 & 32.58 & 21.26 & 5.15 & 33.7 & 24.34 \\
\hline Knee height & 46.9 & 58 & 52.81 & 3.93 & 46.97 & 52.89 & 57.7 \\
\hline Hip breadth & 28.7 & 40 & 34.09 & 3.95 & 28.77 & 35.2 & 39.47 \\
\hline Elbow to elbow breadth & 35.9 & 56.9 & 46.66 & 7.2 & 36.14 & 47.34 & 55.92 \\
\hline Sitting shoulder height & 44.4 & 66.78 & 55.32 & 8.1 & 45.22 & 55.89 & 65.54 \\
\hline Sitting lowest rib bone height & 61 & 84 & 74.45 & 7.06 & 63.57 & 75.8 & 82.95 \\
\hline Sitting upper hip bone height & 55 & 67 & 61.38 & 4.13 & 55.54 & 61 & 64.43 \\
\hline Forearm fingertip length & 40 & 52.5 & 46.32 & 4.35 & 40.56 & 45.78 & 52.08 \\
\hline Buttock popliteal length & 34.7 & 48.1 & 42.15 & 4.79 & 35.54 & 41.29 & 48.065 \\
\hline Stature & 136 & 179 & 159.73 & 13.76 & 136.94 & 164.78 & 176.2 \\
\hline
\end{tabular}

Table 2: Anthropometric measures of the student's.

\begin{tabular}{|c|c|c|}
\hline \multicolumn{2}{|c|}{ Furniture Dimensions } & Dimensions (cm) \\
\hline \multirow{3}{*}{ Chair } & Seat height & 46.5 \\
\cline { 2 - 3 } & Seat width & 43 \\
\cline { 2 - 3 } & Seat depth & 42 \\
\cline { 2 - 3 } & Backrest height & 44 \\
\hline \multirow{2}{*}{ Table } & Table height & 76.8 \\
\cline { 2 - 3 } & Table Width & 60.7 \\
\hline
\end{tabular}

Table 3: Existing classroom furniture 
Ergonomics International Journal

\begin{tabular}{|c|c|c|c|c|}
\hline Furniture dimensions & Match (\%) & $\begin{array}{c}\text { Low } \\
\text { Mismatch } \\
\mathbf{( \% )}\end{array}$ & $\begin{array}{c}\text { High } \\
\text { Mismatch (\%) }\end{array}$ & $\begin{array}{c}\text { Total } \\
\text { Mismatch } \\
\text { (\%) }\end{array}$ \\
\hline Seat Height & 75 & 0 & 25 & 25 \\
\hline Seat Depth & 2 & 0 & 98 & 98 \\
\hline Seat Width & 11 & 0 & 89 & 89 \\
\hline Backrest Height & 42 & 0 & 58 & 58 \\
\hline Table Height & 62 & 38 & 0 & 38 \\
\hline Table Width & 15 & 0 & 85 & 85 \\
\hline
\end{tabular}

Table 4: Number \& percentage of students who match or mismatch with existing classroom furniture.

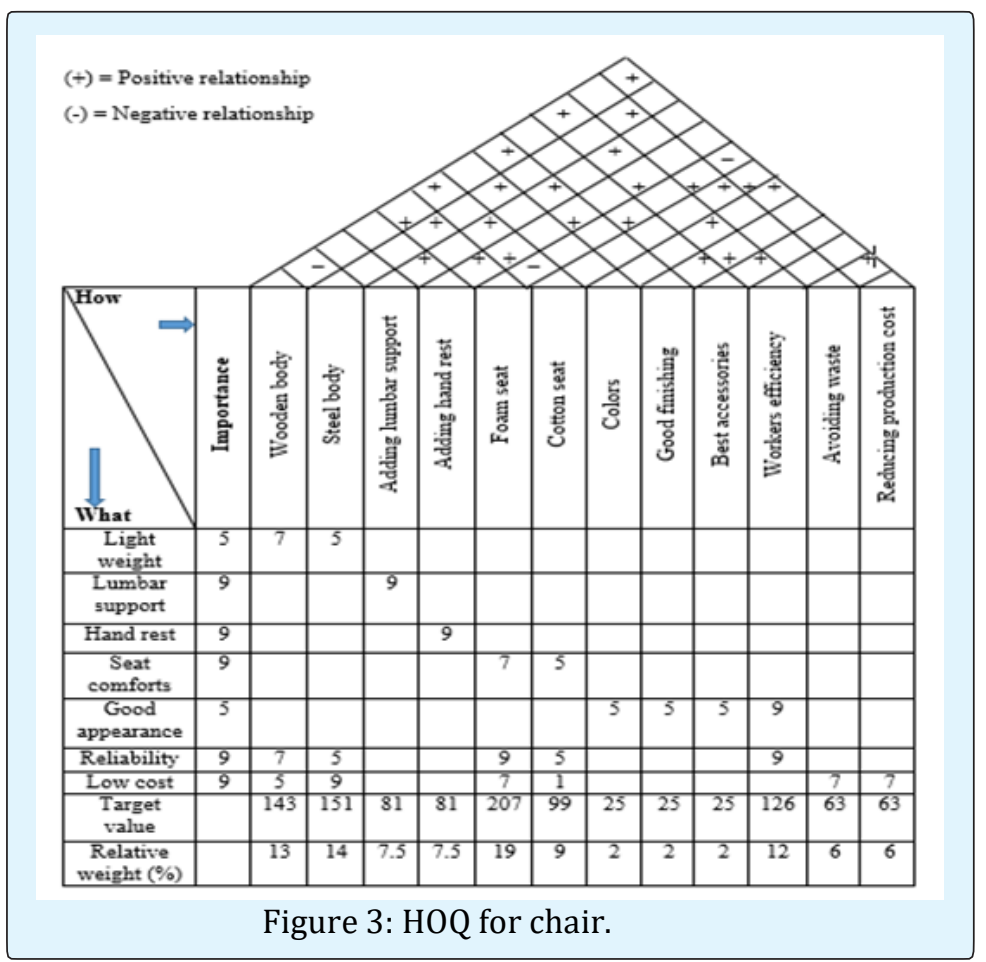

\begin{tabular}{|l|c|c|}
\hline \multirow{2}{*}{ Furniture Dimensions } & Dimensions (cm) \\
\hline \multirow{4}{*}{ Chair } & Seat height & 42 \\
\cline { 2 - 3 } & Seat width & 43 \\
\cline { 2 - 3 } & Seat depth & 42 \\
\cline { 2 - 3 } & Backrest height & 40 \\
\hline \multirow{3}{*}{ Table } & Table height & 74 \\
\cline { 2 - 3 } & Table width & 62 \\
\hline
\end{tabular}

Table 5: Proposed classroom furniture dimensions. 


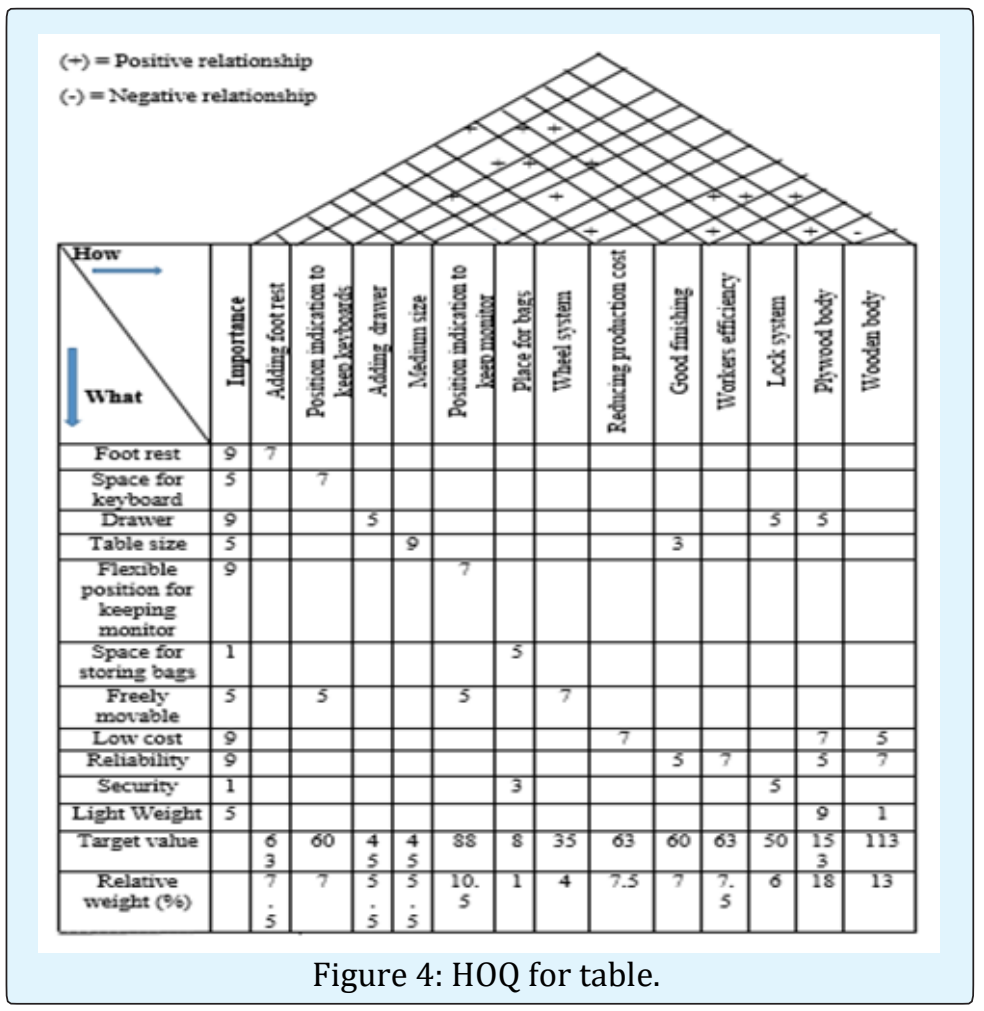

\section{Implementation}

\section{Implementation of Proposed Dimensions}

Finally, proposed chair and table have the correct dimensions for comfortable learning facility. New chair design have the hand rest and lumbar support. New table design have penholder, improved foot rest, wheel for moving and drawer for keeping things. The modification of existing furniture shown in Figure 5 and figure 6 . Figure 5 and Figure 6 showing the modified table and chair.

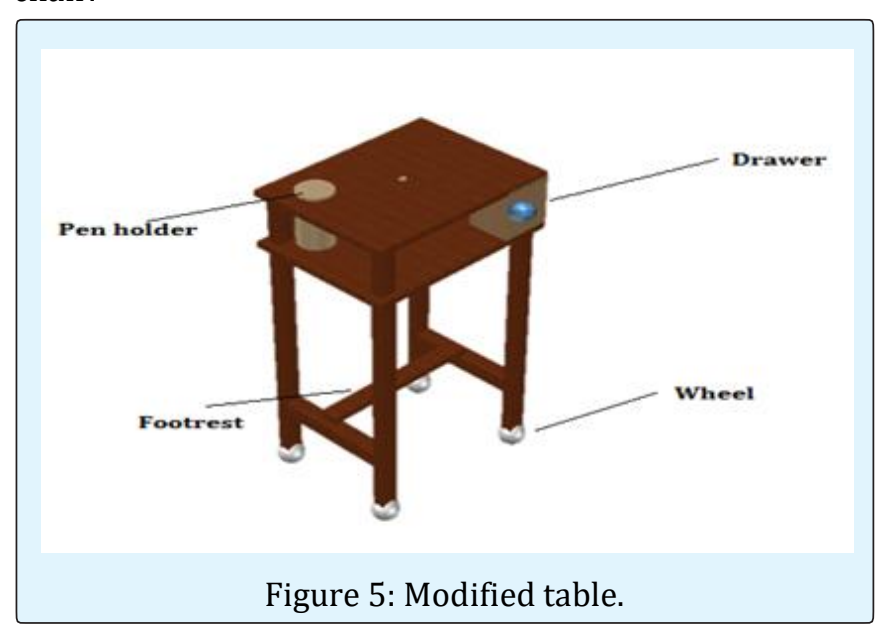

Taposh Kumar K, et al. Ergonomic Design of Table and Chair based on QFD and Anthropometric Measurement and improved Facility Layout. Ergonomics Int J 2018, 2(3): 000146.

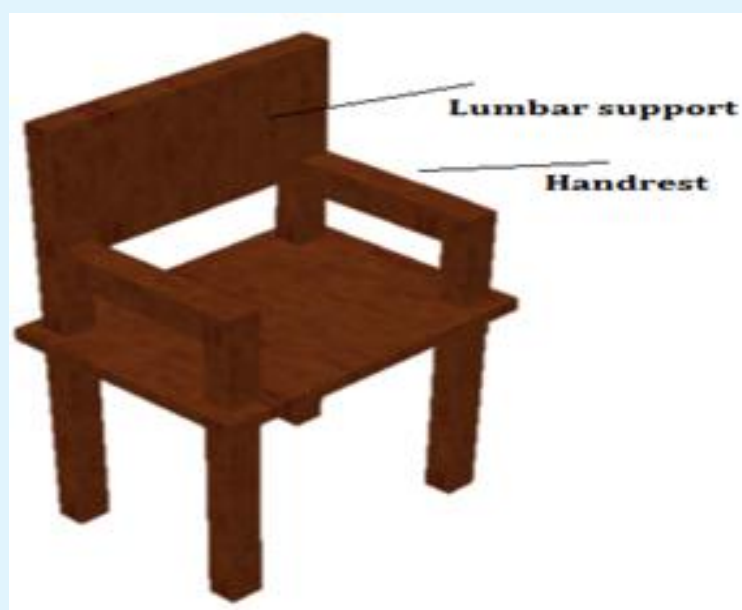

Figure 6: Modified Chair. 


\section{Ergonomics International Journal}

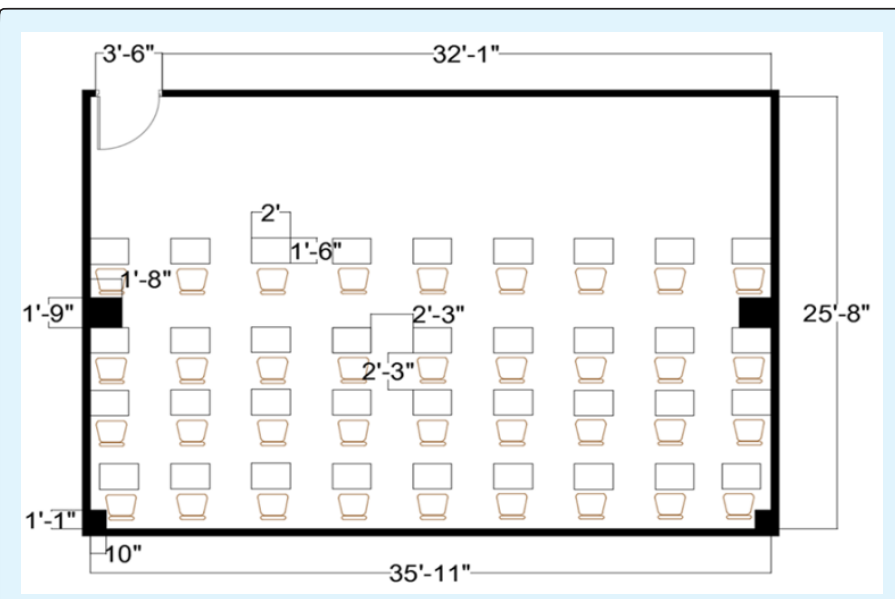

Figure 7: Layout for room no: 233(A), Jessore University of Science and Technology for the proposed table and chair for the present.

\section{Discussion \& Recommendation}

\section{General Discussion}

The study estimated the possible mismatch between classroom furniture and anthropometric characteristics of 200 Bangladeshi university students. The study indicates that, the proposed furniture dimensions are more appropriate than the existing furniture. The proposed dimensions for classroom furniture are also easily adoptable. So, the modified classroom furniture design will be appropriate for almost all university students. However, the proposed dimensions and final implementation of the present study should have some limitations.

\section{Unique Contribution}

The primary aim in this study is to relook at the concept of ergonomically fit table and chair from a new perspective. Listed things are relooked-

- By using Kano model, student's requirement has been very well determined.

- QFD methodology helps a lot to make the appropriate relationship between student's demands and design requirements to overcome the shortcomings.

- According to student's demands new features namely hand rest, proper lumbar support, drawer, pen holder and wheel system are added.

- For the proper allocation of the modified table and chair, a layout is proposed.

\section{Recommendation}

Here, we have some recommendation to provide better learning facility for the university students.

1. The classroom should be sound proof.

2. Air flow system must be developed.

3. Teacher stage should fit with blackboard.

4. The classroom should have air condition system.

5. The classroom furniture must be developed with ergonomic consideration.

6. The chair should be lightweight.

7. The classroom furniture must have best aesthetics, innovative features, and glossy colors.

\section{Limitations}

This study has limitations. Data collection might vary little bit up and down due to movements while collecting. As students' comfort level is emphasized, the price of the proposed table might increase Extra facilities like air condition; sound system can be provided but will incur more costs.

\section{Future Work}

Table desk can be blocked by extra piece of material. Price can be decreased. Chair hand rest should be foamed.

\section{Conclusion}

The sole purpose of this paper was to scrutinize relation between body dimensions from a sample study of 200 Bangladeshi university students and ergonomic classroom furniture design. A remarkable mismatch was identified between student's body dimensions and the classroom furniture (namely chair and table) dimension. Table height of the classroom furniture was low for the students. Also, the seats were high for the students. These conditions may lead to pain and musculoskeletal disorders. This research proposed dimensions that satisfied the anthropometric measurement to reduce the problem. The findings of the study also clearly demonstrate that the design and allocation of classroom furniture for Bangladeshi university students should be made according to anthropometric judgment to avoid unnecessary problems. 


\section{Acknowledgment}

The author would like to thank Dr. A.S.M. Mojahidul Hoque, Chairman of department of Industrial and Production Engineering, Jessore University of Science and Technology and students of department of industrial and production engineering, Jessore University of science and technology, Jessore, Bangladesh, for their uncountable support.

\section{References}

1. Abuzid HFT (2017) Applying QFD Tools for Quality Improvements in Curriculum Design and Teaching Strategies to Meet with the Customer (Learner) Needs. Journal of Engineering and Applied Sciences 12(3): 684-690.

2. Francis F (2016) Engineering Approach with Quality Function Deployment for an ABET Accredited Program: A Case Study. American Journal of Mechanical Engineering 4(2): 65-70.

3. Kunecka D (2016) Quality Function Deployment as a Method Used in the Development of Education for the Nursing Practice. General and Professional Education 1: $42-45$

4. Buttigieg SC, Dey PK, Cassar MR (2016) Combined quality function deployment and logical framework analysis to improve quality of emergency care in Malta. Int J Health Care Qual Assur 29(2): 129-140.

5. Kassela K, Marina Papalexi, David B (2017) Applying quality function deployment to social housing? The TQM Journal 29(3): 422-437.

6. Camgöz Akdağ H, Mehveş Tarım, Subash Lonial, AlimYatkin (2013) QFD application using SERVQUAL for private hospitals: a case study. Leadership in Health Services 26(3): 175-183.

7. Cordeiro EC, Barbosa GF, Trabasso LG (2016) A customized QFD (quality function deployment) applied to management of automation projects. The International Journal of Advanced Manufacturing Technology 87(5-8): 2427-2436.

8. Li X, Wenyan Song (2016) A Rough VIKOR-Based QFD for Prioritizing Design Attributes of Product-Related Service. Mathematical Problems in Engineering 9642018.

\section{Ergonomics International Journal}

9. Bulut Emrah, Okan Duru, Sheng Teng Huang (2016) A multidimensional QFD design for the service quality assessment of Kansai International Airport, Japan. Journal Total Quality Management \& Business Excellence 29(1-2): 202-2024.

10. Muda N, Noor Sulawati Mat Roji (2015) A Quality Function Deployment (QFD) Approach in Determining the Employer's Selection Criteria. Journal of Industrial Engineering 789362.

11. Lonica, Andreea Cristina, Monica Leba (2015) QFD Integrated in New Product Development - Biometric Identification System Case Study. Procedia Economics and Finance 23(2015): 986-991.

12. Kato Takeo, Shigehiro Horiuchi, Toshiharu Miwa, Yoshiyuki Matsuoka (2015) Quality Function Deployment Using Multispace Design Model and its Application. Keio University 5(DS 80-05): 83-92.

13. Moradi M, Raissi S (2014) A Quality Function Deployment Based Approach in Service Quality Analysis to Improve Customer Satisfaction. International Journal of Applied Operational Research 5(1): 41-49.

14. Jin, Jian, Ping Ji, Ying Liu (2014) Prioritising Engineering Characteristics Based on Customer Online Reviews for Quality Function Deployment. Journal of Engineering Design 25(7-9): 303-324.

15. Romeo John, Andrew Smith, Sarich Chotipanich, Michael Pitt (2014) Awareness and effectiveness of quality function deployment (QFD) in design and build projects in Nigeria. Journal of Facilities Management 12(1): 72-88.

16. Cerit B, Küçükyazıcı G, Kalem G (2014) Quality Function Deployment and Its Application on a Smartphone Design. Balkan Journal of Electrical \& Computer Engineering 2(2):86-91.

17. Oyewole Samuel A, Joel M Haight, Andris Freivalds (2010) The ergonomic design of classroom furniture/computer work station for first graders in the elementary school. International Journal of Industrial Ergonomics 40(4): 437-4470.

18. Lin, Rungtai, Yen-Yu Kang (2013) Ergonomic Design of Desk and Chair for Primary School Students in Taiwan. International Journal of Innovation, Management and Technology 4(1):1-6. 


\section{Ergonomics International Journal}

19. Vilarinho PM, Guimaraaes RC (2003) A Facility Layout Design Support System. Investigacao Operacional 23(2): 145-161.

20. Sunderesh S, Heragu (1991) Efficient models for the facility layout problem. European Journal of Operational Research 53(1): 1-13.

21. Ford Angel (2017) Planning Classroom Design and Layout to Increase Pedagogical Options for Secondary Teachers. Educational Planning 23(1): 25-33.

22. Sapna Cheryan, Sianna A Ziegler, Victoria C Plaut, Andrew N Meltzoff (2015) Designing Classrooms to Maximize Student Achievement. Behavioral and Brain Sciences 1(1): 4-12.

23. Ismaila SO, Musa AI, Adejuyigbe SB, Akinyemi OD (2013) Anthropometric Design of Furniture for Use in Tertiary Institutions in Abeokuta, South-Western Nigeria. Engineering Review 33(3):179-192.

24. Molenbroek JF, Kroon-Ramaekers YM, Snijders CJ (2003) Revision of the design of a standard for the dimensions of school furniture. Ergonomics 46(7): 681-694.

25. Molenbroek J, Ramaekers Y (1996) Anthropometric design of a size system for school furniture. In: Robertson SA (Ed.), Proceedings of the Annual Conference of the Ergonomics Society: Contemporary Ergonomics, Taylor \& Francis, London, pp: 130-135.

26. Parcells C, Stommel M, Hubbard RP (1999) Mismatch of classroom furniture \& student body dimensions: Empirical findings \& health implications. Journal of Adolescent Health 24(4): 265-273.

27. Gouvali MK, Boudolos K (2006) Match between school furniture dimensions \& children's anthropometry. Applied Ergonomics 37(6): 765-773.

28. Gutiérrez M, Morgado P (2001) Guía de recomendaciones para el diseñodelmobiliario escolar Chile, Ministerio de Educación and UNESCO, Santiago de Chile.

29. Evans WA, Courtney AJ, Fok KF (1988) The design of school furniture for Hong Kong school children: An anthropometric case study. Applied Ergonomics 19(2): 122-134.

30. Poulakakis G, Marmaras N (1998) A model for the ergonomic design of office. In: Scott PA, Bridger RS, Charteris J (Eds.), Proceedings of the Ergonomics Conference in Cape Town, Global Ergonomics, Elsevier, pp: 500-504.

31. Milanese S, Grimmer K (2004) School furniture and the user population: An anthropometric perspective. Ergonomics 47(4): 416-426.

32. Helander M (1997) Anthropometry in workstation designs. In: $M$ Helander (Ed.), A Guide to the Ergonomics of Manufacturing, Taylor \& Francis, London, pp: 17-28.

33. Orborne DJ (1996) Ergonomics at Work: Human Factors in Design and Development. $3^{\text {rd }}$ (Edn.), John Wiley, Chichester.

34. Khalil TM, Abdel-Moty EM, Rosomoff RS, Rosomoff HL (1993) Ergonomics in Back Pain: A Guide to Prevention and Rehabilitation, Van Nostrand Reinhold, New York, NY.

35. Pheasant S (1991) Ergonomics, Work and Health, Macmillan, Hong Kong.

36. Sanders MS, Mccormick EJ (1993) Applied anthropometry, work-space design and seating. In Human Factors in Engineering and Design, $7^{\text {th }}$ (Edn.), McGraw-Hill, Singapore.

37. Agha SR (2010) School furniture match to students' anthropometry in the Gaza Strip. Ergonomics 53(3): 344-354.

38. Occhipinti E, Colombini D, Molteni G, Grieco A (1993) Criteria for the ergonomic evaluation of work chairs. Le Medicina del Lavoro 84(4): 274-285.

39. García-Acosta G, Lange-Morales K (2007) Definition of sizes for the design of school furniture for Bogotá schools based on anthropometric criteria. Ergonomics 50(10): 1626-1642. 